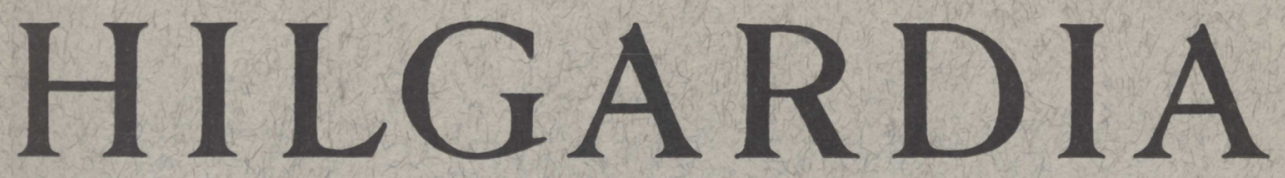

A Journal of Agricultural Science Publisbed by the California Agricultural Experiment Station

\title{
BURROWS OF THE SACRAMENTO VALLEY POCKET GOPHER IN FLOOD-IRRIGATED ALFALFA FIELDS
}

MILTON A. MILLER

UNIVERSITY OF CALIFORNIA - BERKELEY, CALIFORNIA 
This paper discusses patterns and statistical characteristics of burrows dug by the Sacramento Valley pocket gopher (Thomomys bottae navus Merriam) in flood-irrigated alfalfa fields, and the relationship of burrowing activity to soil conditions and irrigation schedules. Suggestions for improvement of gopher control derived from this study are given.

Functionally, a gopher burrow comprises two unequal parts: (1) a loose network of main and lateral feeding tunnels which lie within one foot of the surface (mode at 6-to 8-inch depth) and comprise 80 per cent of total tunnel footage; and (2) a deeper tunnel system which centers at 20- to 22-inch depth and connects with nests and food caches. Typical burrows have several steep tunnels which end blindly at various depths down to nearly seven feet and probably serve for drainage. Burrows concentrate in or near field levees which are often extensively undermined.

Normally, only one gopher inhabits a system, but considerable turnover in occupancy of established burrows is indicated.

The average burrow includes $107 \pm 21$ feet of cylindrical tunnels, $2.6 \pm 0.08$ inches in diameter, giving a volume of $3.87 \pm 0.69$ cubic feet; $8.6 \pm 2.8$ feet of recently plugged tunnel; about two nest chambers and an occasional food cache.

Following flood-irrigation, fresh gopher mounds reappear on about the second day, reach peak production during the latter half of the first week, and then decline to a low level. Burrowing is correlated with soil moisture, the optimum ranging between 15 and 17 per cent with markedly less mounds produced under wetter or drier conditions.

Between irrigations, each gopher excavates a daily average of $5.13 \pm 0.71$ pounds of soil (dry weight), an annual turnover (at this rate) of about a ton. 


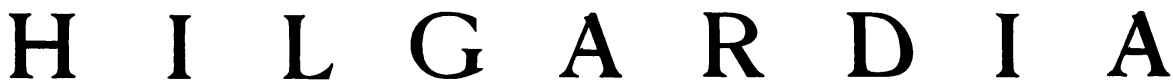

A Journal of Agricultural Science Published by

the California Agricultural Experiment Station

VoL. 26

JANUARY, 1957

No. 8

\section{BURROWS OF THE SACRAMENTO VALLEY POCKET GOPHER IN FLOOD-IRRIGATED ALFALFA FIELDS ${ }^{1}$}

\section{MILTON A. MILLER}

THE SOLITARY pocket gopher spends most of its lonely life secluded in a closed system of underground tunnels. Since a knowledge of gopher burrows is an invaluable aid in controlling this important agricultural pest, studies were made of burrowing by the Sacramento Valley pocket gopher (Thomomys bottae navus Merriam) in irrigated fields of the University of California at Davis. The major objectives were to: (1) determine the pattern of gopher burrows in flood-irrigated alfalfa fields, both in horizontal and vertical profile; (2) analyze the relationship between burrowing activity and the topography of the field, particularly the distribution of tunnels in relation to field levees ; (3) establish average dimensions and other statistical characteristics of burrows; (4) determine rates of digging, particularly in relation to time following flood-irrigation and to soil moisture; (5) estimate the rates of soil turnover by the gopher; and (6) determine practical applications of the data in gopher control.

\section{LITERATURE}

In a recent review of literature on pocket gopher burrowing, Howard and Ingles $(1951)^{3}$ cite general accounts and list articles to date dealing with various ecological aspects of the subject including: (1) plan of burrows ; (2) rates of digging and description of the burrowing process ; (3) effects on soil formation, erosion, and ecological succession; (4) influence of soil type, soil moisture and other environmental factors on burrowing; (5) tunneling of gophers in snow; and (6) use of burrows by other animals. More recently, Ingles (1952) has contributed a valuable article on the ecology of a montane species, which includes much pertinent data on its burrows. The extensive damage done by gophers and their burrowing, especially to agriculture in the western United States, has been summarized (Miller, 1953) ; losses resulting from burrowing in irrigation systems may exceed those caused by direct destruction of crops eaten or damaged by this rodent.

\section{METHODS}

To determine patterns, dimensions, and related data on gopher burrows, nine systems were carefully excavated, measured, and mapped. The burrows were

${ }^{1}$ Submitted for publication March 13, 1956.

2 Professor of Zoology and Zoologist in the Experiment Station, Davis.

"See "Literature Cited" for citations, referred to in the text by author and date. 
located in a five-year-old flood-irrigated alfalfa field rather heavily infested with gophers. This field had previously been used for poison-bait trials, but no tests had been conducted there for at least a half year prior to this study which was made during the summer.

Before the burrows were excavated, their occupants were removed by trapping. Since systems are sometimes inhabited by more than one gopher (as in breeding season) and since new occupants may quickly move into vacant burrows, traps were reset in each burrow until no new eatches were made and no sign of fresh mounds or plugging was observed for two successive days prior to excavation. The number, sex, size, and breeding condition of gophers trapped in each system were recorded to determine if there was any correlation of these data with the physical characteristics of the burrows.

During excavation, a piece of rubber hose was inserted into each tunnel, ahead of the shovel, to facilitate tracing its course. As excavated, all tunnels, surface mounds, food caches, nests, and other parts of the system were measured and their locations plotted on a scale map. Both horizontal and vertical diameters of tunnels were measured at eight to 13 representative locations in each system. As tunnels are roughly circular in cross-section and no obvious correlation between diameter and depth of tunnels was noted, all measurements for each system were pooled to obtain the average diameter of tunnels in each burrow. Means of measurements and other quantitative data for the various parts of the nine systems were calculated to obtain the dimensions of an "average burrow system."

In addition, burrowing rates after irrigation and in relationship to soil moisture were studied in eight burrow systems in two other alfalfa fields (one- and two-year stands). These new fields were so sparsely infested with gophers that the limits of individual systems could easily be determined. The eight systems selected for study were observed daily for 14 to 16 days following irrigation. Five of these were observed every other day for an additional two weeks. At each observation the following data were recorded: (1) number of new surface mounds and earth plugs ; (2) total weight of soil in surface mounds (later corrected to dry weight) ; (3) moisture content of the soil at six- to twelve-inch depth; and (4) soil temperature at one-foot depth. Air temperatures (daily average) and precipitation data for the period of study were obtained from University records.

\section{RESULTS AND DISCUSSION}

\section{General Considerations}

The burrow serves the gopher for shelter, protection from enemies, as a means for obtaining and storing food, and as a place for rearing the young. As Ingles (1952) points out, the burrow system constitutes the gopher's "home range" or "territory." Normally, only one individual occupies a system, as these unsocial rodents are extremely antagonistic to one another. In breeding season, however, a pair or a female with litter may be found together.

Young gophers, shortly after weaning, disperse overland from the maternal burrow and each soon excavates its own tunnel system. Older gophers sometimes abandon their burrows, dig new ones, or reoccupy old ones. Once estab- 


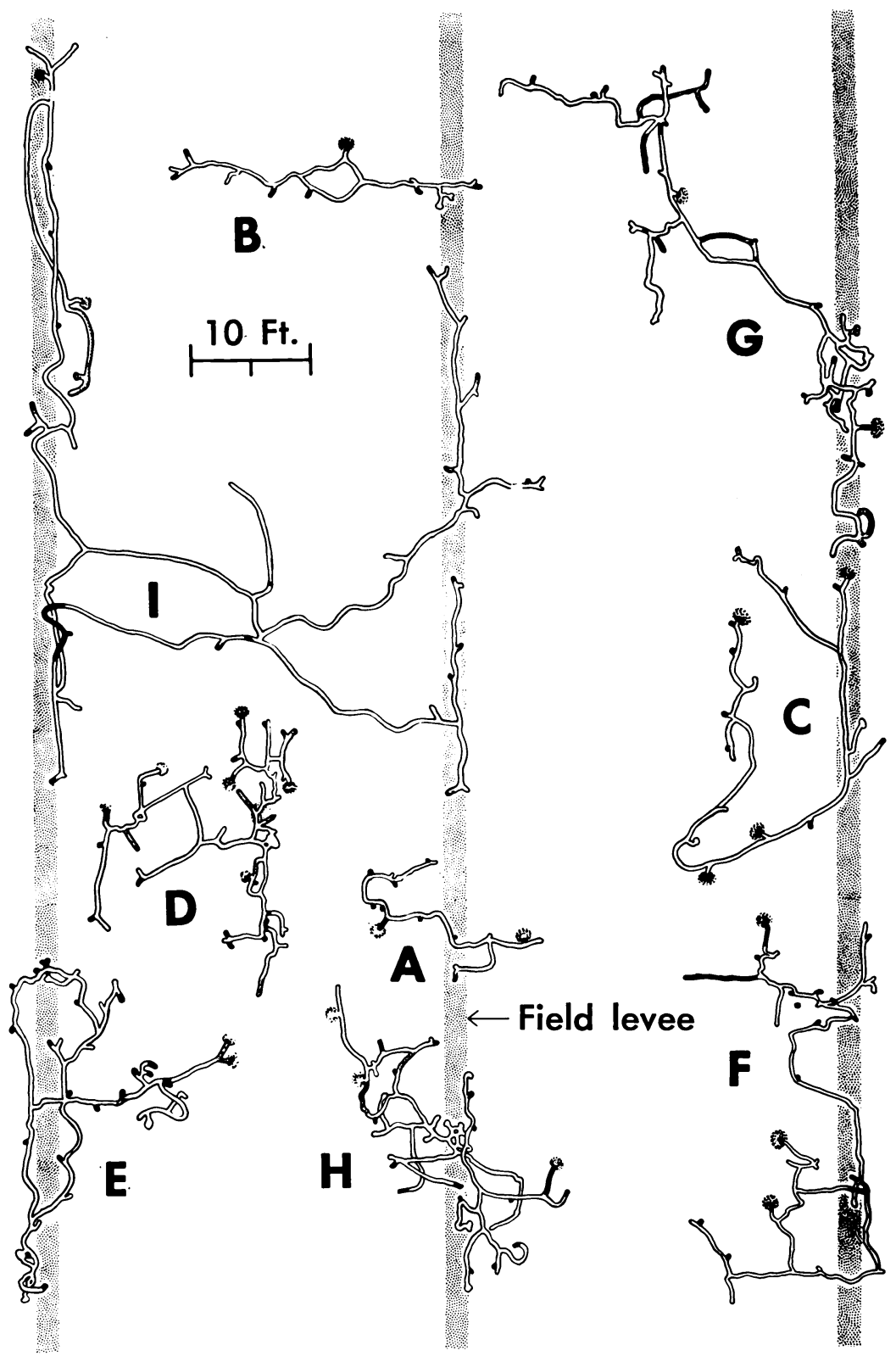

Fig. 1. Scale maps of nine gopher burrows (A-I, table 1) excavated in a flood-irrigated alfalfa field at Davis, California, showing their pattern and relation to field levees. For convenience, the burrows have been rearranged, but otherwise their spatial relationships are essentially the same as in the field. Surface view as through transparent soil; depths not indicated. (For finer details of a burrow system, see fig. 2). 
lished, the animals emerge from their burrows only occasionally (mostly between dusk and dawn) to forage on the surface, to push out excavated soil, or for other purposes. Gophers are obviously most vulnerable to predators, notably owls, when outside their burrows.

The burrow consists of an underground network of branching and anastomosing tunnels with attached subterranean nests and food cache chambers. It is essentially a closed system because all surface connections are plugged with earth when not actually being used. Moreover, the gopher will

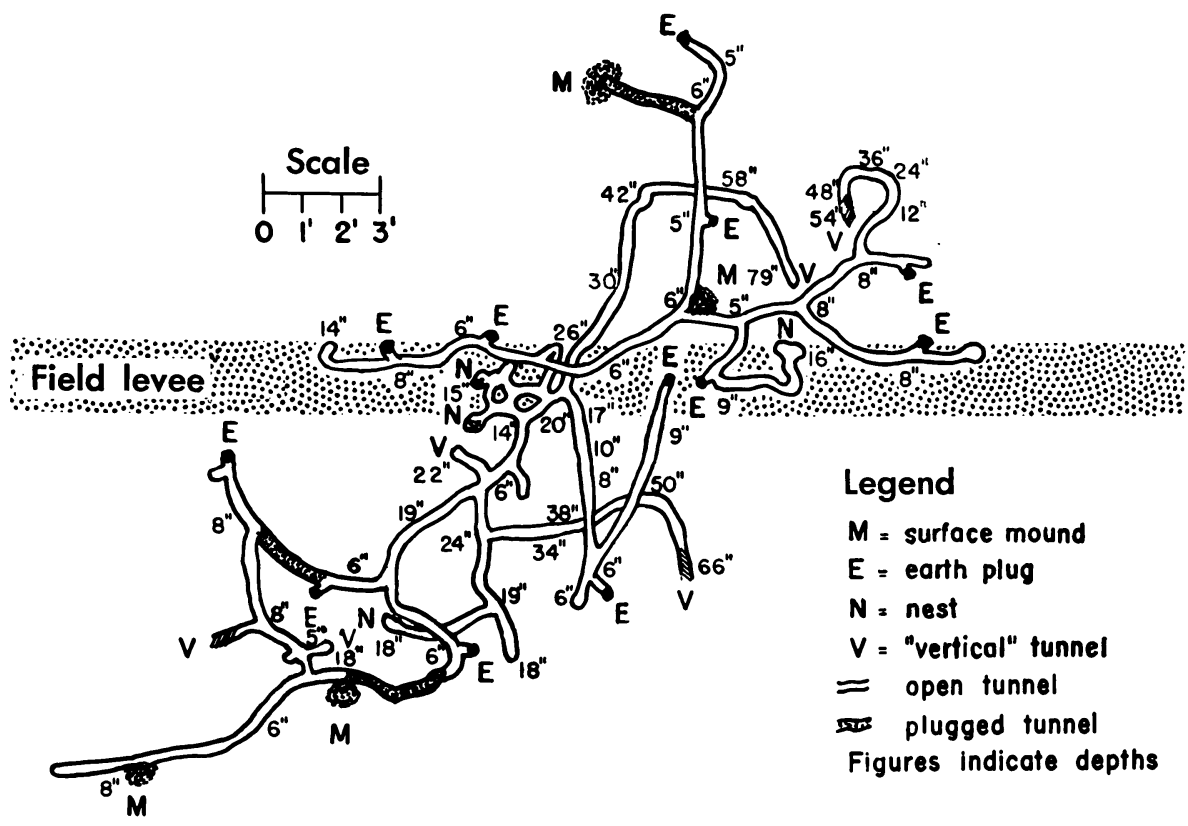

Fig. 2. A large gopher burrow system ( $H$, table 1$)$ excavated in a flood-irrigated alfalfa field at Davis.

quickly seal with packed soil any eave-in, erack, or other opening into its burrow. Presumably, this behavior pattern is instinctive and certainly protective against enemies such as the gopher snake. What stimulates the plugging reaction is not known, but sensitivity to light, to drafts, or to thermal changes have been suggested.

For digging tools, the gopher uses its protruding, chisel-like incisors and the enlarged claws on its short, powerful forelegs, both being nicely adapted for rapid digging. The furry sides of the mouth can be drawn together medially through the toothless gap (diastema) between the incisors and molars to prevent dirt entering the oral cavity during excavations. The soil loosened by tooth and claw is pushed backward between the hind legs of the industrious miner. When enough of a pile has accumulated, the slim-hipped gopher turns quickly about in its narrow tunnel and, with fore-paws cupped under its chin, bulldozes the loose soil to the surface or into another part of the burrow. 
Soil pushed to the surface forms aptly named "excavation mounds." These vary greatly in size depending presumably on the amount of digging done by the gopher when they were formed. The distinctive crescentic shape of gopher mounds results from the fan-wise distribution of successive loads of excavated earth pushed out in an arc around the front and sides of the tunnel mouth. The last loads of earth are used to close this opening. The plugged tunnel entrance can usually be located near the center edge of the crescentshaped mound as a circular depression caused by the settling of the closing
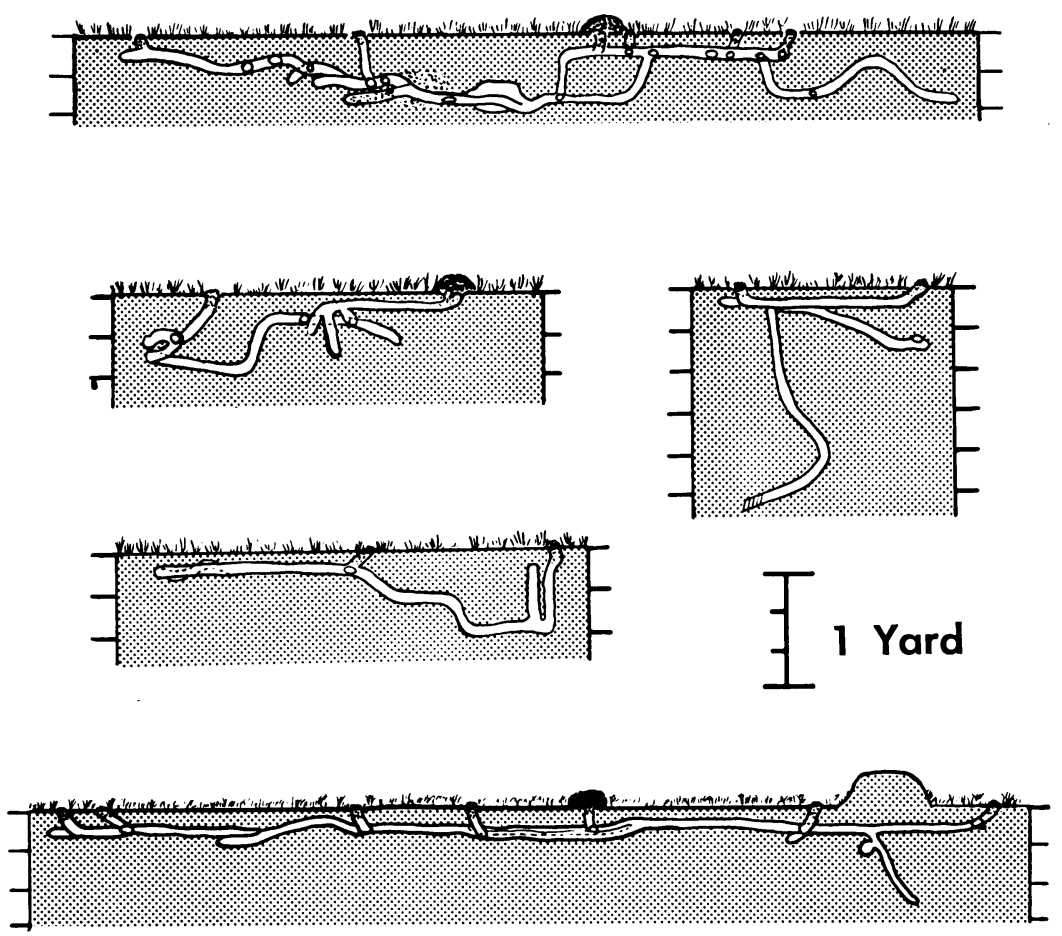

Fig. 3. Typical vertical transects of gopher burrow systems excavated in a flood-irrigated alfalfa field at Davis.

plug. The distribution of excavation mounds roughly indicates the area undermined by a gopher system, while their number and size suggest its magnitude.

Another indicator of gopher burrows is the earth plug which seals temporary exits from the burrow. Unlike excavation mounds, earth plugs are more or less flush with the surface and hence not so easily detected.

Not all the excavated earth is pushed to the surface, much of it being disposed of in other parts of the burrow, especially in unused laterals or old food caches or nest chambers. Sometimes even main runs may be plugged for considerable distances. Thus, the burrow is constantly being remodeled as well as enlarged by the dynamic tenant. 


\section{Patterns of Burrows in Alfalfa Fields}

Plans of gopher burrows in irrigated alfalfa fields are shown in figures 1 to 3 , and quantitative data concerning the nine excavated systems are summarized in table 1 and figure 4. They are basically similar to burrows in other situations but with certain differences.

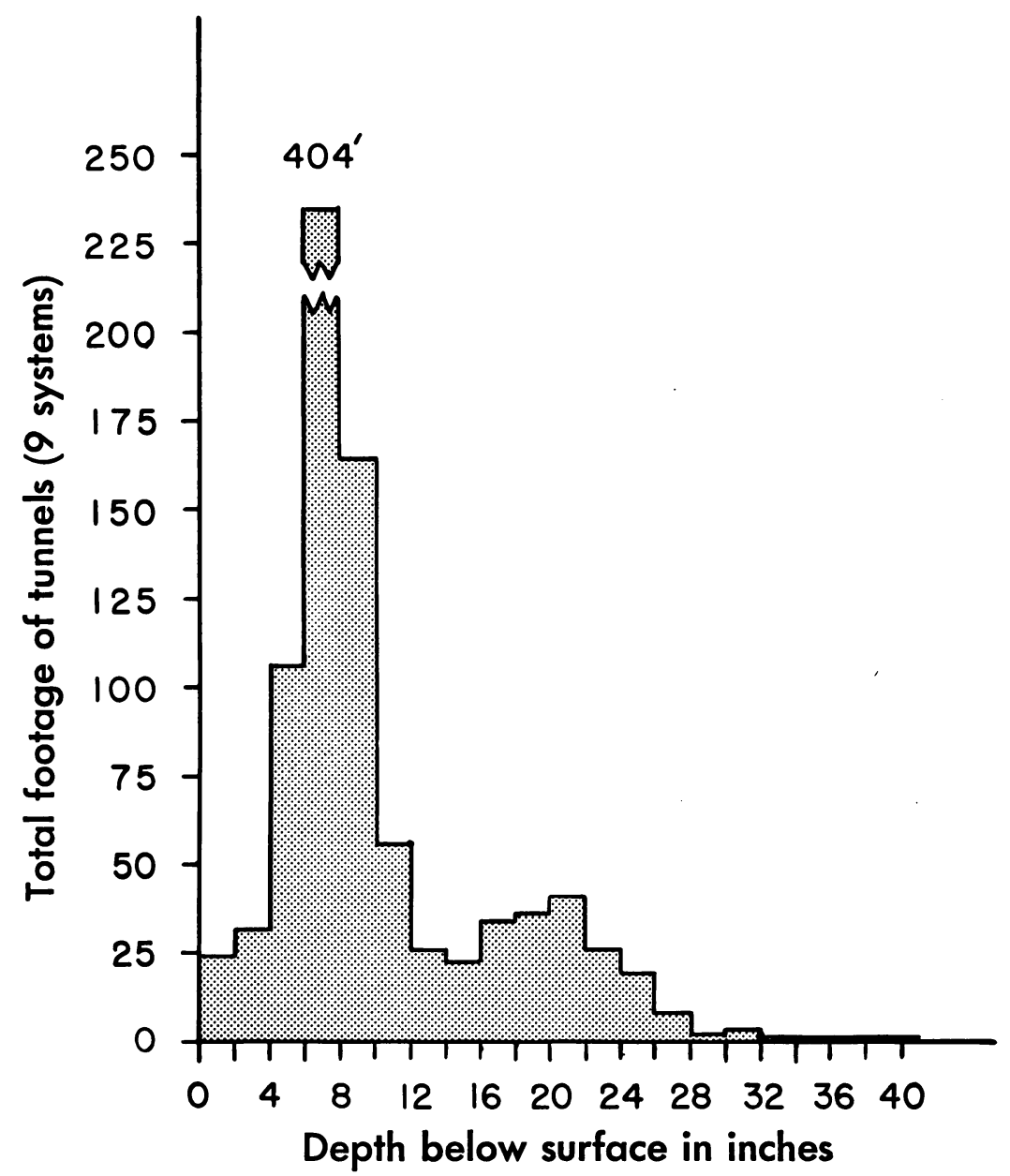

Fig. 4. Frequency distribution of gopher tunnels in relation to depth for nine burrows excavated in a flood-irrigated alfalfa field at Davis.

Tunnels. Each system has at least one, but usually several, main tunnels which run more or less parallel to the ground surface at relatively shallow depths. The modal depth is between six and eight inches, which contains nearly 40 per cent of the total tunnel footage, while 65 per cent of the tunnels lie between four- and ten-inch depths (fig. 4). A deeper horizontal system was observed with a submode centering at 20 to 22 inches. Deep tun- 
nels often lead to or connect with food caches and nest chambers which, with one exception, were at least a foot beneath the ground with an average depth of about 18 inches.

The longer horizontal tunnels have laterals at frequent but irregular intervals. Many short laterals ascend to the surface, where they terminate either in excavation mounds or in earth plugs. Other laterals end blindly underground.

The main superficial tunnels together with their laterals are dug by the gopher presumably to obtain the fleshy roots and tubers on which it feeds. Hence, they constitute what has been called the "feeding tunnels" to differentiate them from the deeper parts of the burrow system which are used primarily for nesting and food storage. Tryon (1947) states that the feeding tunnels are of slightly smaller diameter than the deeper shelter tunnels, but no such correlation was found in our data. However, more refined measurements and analysis are needed before final conclusions can be made on this point.

Vertical tunnels are of two sorts-those connecting between horizontal tunnels at different depths; and steeply pitched shafts originating from horizontal tunnels and ending blindly at a greater depth. All but the shortest burrow system studied had from one to as many as six blind vertical tunnels. One was only three inches long, but most of them ranged in length from a foot to nearly five feet. The longest two, both in the same system $(\mathrm{H})$, terminated in silt below the ground surface at $51 / 2$ and $61 / 2$ feet, respectively.

The function of the blind verticals is not established. Storer (1953) suggests they may serve as "sumps" to drain adjacent tunnels. The presence of considerable silty material at the bottom of these verticals supports this suggestion. Without leading into some porous substrate, however, such sumps could handle only a limited amount of drainage, as lateral seepage in soil is negligible. They could probably drain normal seepage from rainfall, but would not protect the burrow for long against flooding during heavy irrigation. Many gophers are forced out of their burrows during irrigation of alfalfa fields, which shows that burrows are inadequately protected against flooding. The lack of any appreciable enlargement at the end of these vertical shafts rules out the possibility of their use as a den or nest chamber. There is also no evidence that they serve as fecal depositories.

Open tunnels of all types in the nine excavated systems ranged from 31 to 275 feet in length with an average of 107 feet. The average diameter was 2.6 inches. Considering each system as a cylinder with a height $(\mathrm{h})$ equal to the total length of tunnels and a base equal to its average diameter (d), volumes of systems $(\mathrm{v})$ can be easily calculated by the formula: $\mathrm{v}=\pi(\mathrm{d} / 2)^{2} \mathrm{~h}$. Estimates of volume range from 1.06 to 7.95 cubic feet with an average of 3.87 cubic feet per burrow. The weight of soils removed in excavating these tunnels can be calculated on the basis that one cubic foot is equivalent to 80 pounds (specific gravity of about 1.3). Thus, equivalent weights of excavated soil range from about 85 to 636 pounds with an average of 309.6 pounds per burrow. The foregoing values are minimal since they do not include excavated earth deposited underground in tunnels, food caches, and nest chambers.

Plugged tunnels ranged in length from zero (in three burrows) to 28 feet 
TABLE 1. FEATURES OF NINE POCKET GOPHER BURROWS EXCAVATED IN

\begin{tabular}{|c|c|c|c|c|c|c|c|c|c|c|c|}
\hline \multirow{2}{*}{$\begin{array}{l}\text { Tunnel } \\
\text { system }\end{array}$} & \multicolumn{2}{|c|}{$\begin{array}{l}\text { Surface } \\
\text { workings }\end{array}$} & \multicolumn{2}{|c|}{$\begin{array}{l}\text { Length of } \\
\text { tunnels }\end{array}$} & \multirow{2}{*}{$\begin{array}{c}\text { Average } \\
\text { diameter } \\
\text { and range }\end{array}$} & \multicolumn{2}{|c|}{ Volume } & \multirow{2}{*}{$\begin{array}{c}\text { Blind, steep, or } \\
\text { vertical tunnels. } \\
\text { Number and } \\
\text { depth range }\end{array}$} & \multicolumn{3}{|c|}{ Food caches } \\
\hline & Mounds & Plugs & Open & Plugged & & Open & Plugged & & Depth & Size & Contents \\
\hline & $\begin{array}{c}\text { (num- } \\
\text { ber) }\end{array}$ & (num- & (ft.) & (ft.) & (inches) & $\begin{array}{l}\text { (cu. } \\
\text { ft.) }\end{array}$ & (cu. ft.) & (no., inches) & $\begin{array}{l}\text { (inch- } \\
\text { es) }\end{array}$ & (inches) & \\
\hline A...... & 2 & 8 & 31 & 0 & $\begin{array}{l}2.5 \pm 0.08 \\
(2.0-3.0)\end{array}$ & 1.06 & $\ldots$ & 0 & .. & none & $\ldots \ldots$ \\
\hline B..... & 1 & 6 & 45 & 0 & $\begin{array}{r}2.56 \pm 0.12 \\
(2.0-3.0)\end{array}$ & 1.61 & $\ldots$ & $1,9-32=23$ & . & none & $\ldots \ldots$ \\
\hline $\mathrm{C} \ldots \ldots$ & 4 & 9 & 83 & 0 & $\begin{array}{r}2.35 \pm 0.09 \\
(1.5-3.0)\end{array}$ & 2.50 & $\ldots$ & $\begin{array}{l}2,8-26=18 \\
2,8-22=14 \\
1,8-18=10 \\
1,0-26=26\end{array}$ & 19 & $3.5 \times 5.5 \times 6$ & $\begin{array}{l}\text { Cut alfalfa filling } \\
\text { entire chamber }\end{array}$ \\
\hline D.... & 6 & 14 & 93 & 13 & $\begin{array}{l}2.74 \pm 0.11 \\
(2.0-3.75)\end{array}$ & 3.8 & 0.53 & $\begin{array}{l}1,0-16=16 \\
4,8-20=12\end{array}$ & . & none & $\ldots \cdots$ \\
\hline E...... & 2 & 16 & 102 & 8.5 & $\begin{array}{l}2.6 \pm 0.08 \\
(2.0-3.25)\end{array}$ & 3.84 & 0.32 & $\begin{array}{l}1,5-20=15 \\
1,7-16=9 \\
1,8-20=12\end{array}$ & . & none & $\ldots \ldots$ \\
\hline F...... & 4 & 12 & 104 & 9 & $\begin{array}{r}2.35 \pm 0.09 \\
(1.75-3.0)\end{array}$ & 3.14 & 0.27 & $\begin{array}{l}2,8-23=15 \\
1,0-13=13 \\
1,8-20=12 \\
1,6-17=11\end{array}$ & 18 & $5.75 \times 5 \times 4.75$ & $\begin{array}{l}\text { Cut dried alfalfa } \\
\text { tops, and stems } \\
\left(1 / 4^{\prime \prime} \text { diam. } \times 1 \text { " }\right. \\
\text { length) }\end{array}$ \\
\hline G.... & 2 & 12 & 114 & 28 & $\begin{array}{r}3.13 \pm 0.10 \\
(2.0-3.75)\end{array}$ & 6.10 & 1.50 & $\begin{array}{l}1,10-18=8 \\
1,7-18=11 \\
1,7-22=15\end{array}$ & . & none & $\ldots \ldots$ \\
\hline H.... & 4 & 12 & 118 & 9 & $\begin{array}{r}2.75 \pm 0.14 \\
(1.5-4.0) \\
\end{array}$ & 4.87 & 0.37 & $\begin{aligned} 1,8-18 & =10 \\
1,5-18 & =13 \\
1,24-66 & =42 \\
1,6-22 & =16 \\
1,20-79 & =59 \\
1,8-54 & =46\end{aligned}$ & . & none & $\ldots \ldots$ \\
\hline I...... & 2 & 15 & 274.5 & 9.75 & $\begin{array}{l}2.3 \pm 0.11 \\
(1.25-3.5)\end{array}$ & 7.95 & 0.28 & $\begin{array}{l}1,6-24=18 \\
1,6-20=14 \\
1,7-24=17 \\
1,7-10=3 \\
1,6-22=16\end{array}$ & . & none & $\ldots \ldots$ \\
\hline $\begin{array}{l}\text { Mean士 } \\
\text { S.E. } .\end{array}$ & $\begin{array}{l}3 \pm \\
0.5\end{array}$ & $\begin{array}{c}11.6 \pm \\
1.0\end{array}$ & $\begin{array}{c}107.2 \pm \\
20.7\end{array}$ & $\begin{array}{l}8.6 \pm \\
2.8\end{array}$ & $\begin{array}{c}2.59 \pm \\
0.08\end{array}$ & $\begin{array}{l}3.87 \pm \\
0.69 \mathrm{ft}^{3}\end{array}$ & $\begin{array}{c}0.36 \pm \\
0.15 \mathrm{ft}^{3}\end{array}$ & $\begin{array}{lc}3.8 \pm & 17.9 \pm \\
0.7 & 2.3\end{array}$ & 18.5 & & \\
\hline
\end{tabular}

* In system A, the two gophers were caught at the same time. In B, the four gophers were caught in succession in the order listed

with an average of 8.6 feet per burrow. Estimated volumes of plugged tunnels are from zero to 1.5 cubic feet per burrow with a weighted average of 0.36 cubic feet. Corresponding weights are 120 pounds at the upper extreme, and an average of about 29 pounds per burrow.

Theoretically, the sum of soil volumes in mounds, earth plugs, plugged runs, and filled underground chambers should equal the total volume of 
A SIX-YEAR FLOOD-IRRIGATED ALFALFA FIELD AT DAVIS, CALIFORNIA

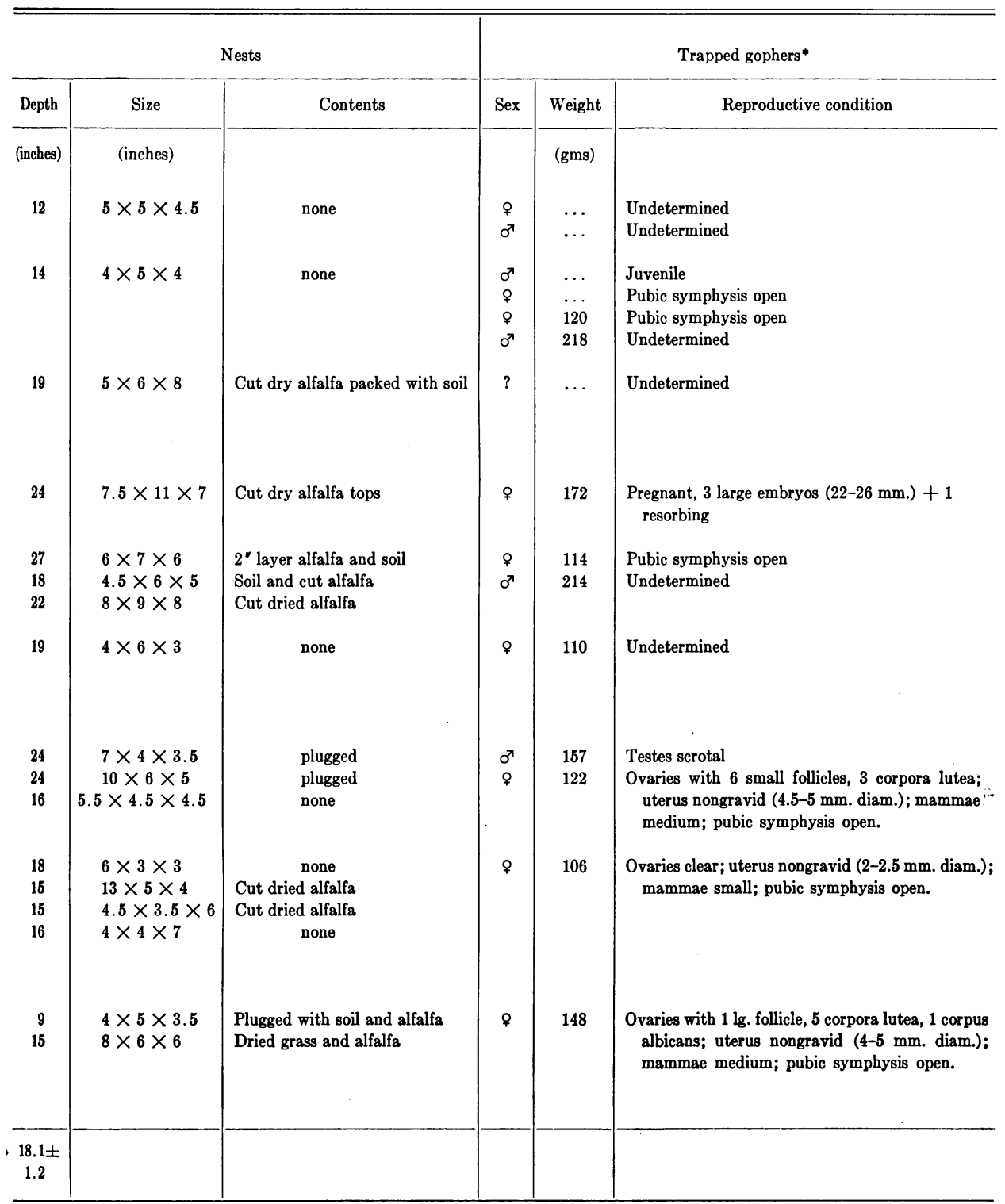

on June $16,19,20$, and 21 . In $\mathrm{E}$, the female was trapped in the morning, the male in the afternoon of the same day.

excavation in any given system, and the volume of surface mounds should be roughly equivalent to the volume of open tunnels and underground chambers of the system. Comparison of these values (tables 1 and 2), however, clearly indicates that much of the excavated soil is not accounted for. Less than $1 / 10$ of the soil from open tunnels appears in observably plugged runs, and too few mounds and earth plugs were observed to make up the difference. The obvious 
explanation for these discrepancies is that both the footage of plugged tunnels and the number and size of surface mounds are greatly underestimated. Surface mounds become washed away or badly eroded by rain and flood irrigation. Many are so overgrown and obscured by vegetation that they are difficult or impossible to detect. Plugged tunnels, as previously mentioned, tend to blend with the surrounding soil and become indistinguishable in course of time.

The tunnel lengths herein given average somewhat shorter than those reported by other authors. This may be attributed to the greater concentration of food and gophers in alfalfa fields compared with that in other areas, although the age of the system may also be a factor. Tryon (1947) states that about 150 to 200 feet of feeding tunnel are all that are maintained at any particular time in a single system by Thomomys talpoides in the Bridger Mountains of Montana, but he gives no dimensions for the deeper though much less extensive tunnels of the system. The burrow figured by Storer (1953), presumably in or near a barley field, comprised about 226 feet of open tunnel and 64 feet of plugged tunnel.

Mounds. Two types of surface works are distinguishable, excavation mounds and earth plugs (both previously described). The number of excavation mounds observed was surprisingly small and seemed to bear no clear correlation with the length of tunnels (table 1 ). Mounds ranged from one to six with an average of only three per system, or one mound for each 36 feet of open tunnel on the average. The longest system (I) with 275 feet of open tunnel had only two excavation mounds, while a near-average system (D) with 93 feet of open tunnel had six.

Gophers ordinarily produce many more mounds than indicated by the above data. As evidence of this assertion, table 2 shows that, in another alfalfa field, gophers produced more than 25 new mounds per burrow system in but two to four weeks after an irrigation. Furthermore, Storer (1953) figures a typical gopher system excavated at Davis which had 35 mounds for 226 feet of tunnel, a ratio of one mound to $6 \frac{1}{2}$ feet. The seeming paucity of mounds in the present analysis can most likely be attributed to the disappearance of many because of erosion by rain or flood irrigation and overgrowth by vegetation. Disposal of excavated earth underground in abandoned tunnels and elsewhere could account in part for the scarcity of surface mounds.

Food Caches and Nests. Only two of the nine systems ( $\mathrm{C}$ and F) had food caches (one each). These were relatively deep, one 18 inches, the other 19 inches below ground level. The two cache chambers were roughly ovoid in shape with long diameters of 5.75 and 6 inches. They were filled, as might be expected, with cut alfalfa stems. Since alfalfa plants remain in the field throughout the year sometimes for six years or so, and since these systems were dug open during the summer period when the crop was abundant, the lack of food caches in most of the burrow systems was not too surprising. Most of the nests contained cut dry alfalfa, but this was often packed with soil and probably served more for comfort than for food.

All nine systems had one to four nest chambers each. With one exception, they were at least one foot beneath the surface, and most were at depths of 18 to 24 inches. They, too, were more or less ovoid in shape with long diam- 
eters from five to 11 inches. Of a total of 17 , six were empty; three were filled with soil or in one instance soil and alfalfa; and the remaining eight had a flooring either of cut dried alfalfa (four burrows), or dried grass and alfalfa (one burrow), or dry alfalfa packed with soil (three burrows).

Relation of Burrow Dimensions to Occupants. Although it would be desirable to correlate data on size and reproductive condition of the occupant with burrow dimensions and mound building, such is not possible under the conditions of this study. As implied earlier, the gophers removed from a given system over a period of time do not necessarily indicate the number of animals occupying the burrow together. It is highly unlikely, for example, that the four gophers trapped in succession from system B (table 1) were occupying that burrow simultaneously. Furthermore, and more importantly, the first one trapped therein may not have been the original excavator. Even when only one animal is caught in a system, which is usually the case, there is no guarantee that it was the original occupant. Since gophers probably do not live more than three years on the average (Ingles, 1952), it is logical to assume that at least the larger burrows in this six-year alfalfa field were older than their inhabitants, and probably had a succession of tenants. Many gophers are driven from their burrows during flood-irrigation. Some may succumb to predation; others may shift their territories and take over vacant systems. These factors probably account for the poor correlation seen in table 1 between length, diameter, and/or volume of burrows and size of the gophers trapped from them. Although the largest system (I) contained a rather large 148 gram female, the second largest $(\mathrm{H})$ was occupied by a below-average-size female weighing 106 grams, and the largest specimen trapped-a 218 gram male--was taken from the second smallest system (B). (The mean weights for males and females of this species are 153 grams and 112 grams, respectively [Miller, 1952]). Because of too few data and the other complications mentioned, calculation of coefficients of correlation would be meaningless. A similar lack of correlation was observed by Ingles (1952) in comparing the areas and linear dimension of burrows occupied by adult females, adult males, and juveniles. He states that "the home range appears to be about equally variable for all of these age and sex groups." $\mathrm{He}$ considered, therefore, that the length of time occupied, the available space, and whether or not the burrow was established over an old system were the important factors involved, rather than size of occupant.

Relation of Burrow Systems to Field Levees. Scale maps of burrow systems (fig. 1) confirm the belief of experienced operators that gopher burrows tend to lie in or close to field levees. (These are low, parallel ridges of earth about 10 yards apart, between which water flows during irrigation.) When fields are flooded, gophers often leave their burrows and make for the higher ground on the levees. As the water recedes, they dig into the levees with a good chance of striking an existing tunnel to appropriate. It is not surprising therefore to find the greater part of burrow systems distributed in or near levees. Only one system (D) had no part in or under a field levee. Ancestral burrows must facilitate re-invasion of alfalfa fields by gophers.

In old alfalfa fields (some stand five or more years), practically every levee seems to be undermined by horizontal tunnels along much of its length. This 
TABLE 2. BURROWING ACTIVITY OF THE SACRAMENTO VALLEY DAVIS, YOLO COUNTY, CALIFORNIA, IN RELATION TO

\begin{tabular}{|c|c|c|c|c|c|c|c|c|c|c|}
\hline \multirow{3}{*}{$\begin{array}{l}\text { Days after } \\
\text { irrigation }\end{array}$} & \multirow{2}{*}{\multicolumn{2}{|c|}{ Soil conditions* }} & \multicolumn{8}{|c|}{ Tunnel systems J-N in six-year alfalfa field (Aug. 7-Sept. 3) } \\
\hline & & & \multicolumn{2}{|c|}{$\mathrm{J}$} & \multicolumn{2}{|c|}{$\mathbf{K}$} & \multicolumn{2}{|c|}{$\mathrm{L}$} & \multicolumn{2}{|c|}{ M } \\
\hline & Moisture & Temp. & Mounds & Dry wt. & Mounds & Dry wt. & Mounds & Dry wt. & Mounds & Dry wt. \\
\hline & (per cent) & $\left({ }^{\circ} \mathrm{F}\right)$ & (no.) & (lbs.) & (no.) & (lbs.) & (no.) & (lbs.) & (no.) & (lbs.) \\
\hline 1. & 19.5 & $\ldots$ & 2 & 8.4 & 0 & 0 & 0 & 0 & 1 & 0.8 \\
\hline 2. & 18.9 & $75^{\circ}$ & 1 & 16.9 & 0 & 0 & 0 & 0 & 0 & 0 \\
\hline 3. & 18.4 & $75^{\circ}$ & 1 & 8.5 & 0 & 0 & 7 & 5.9 & 1 & 2.5 \\
\hline 4.. & 17.9 & $73^{\circ}$ & 2 & 16.2 & 0 & 0 & 1 & 5.2 & 0 & 0 \\
\hline 5. . & 17.4 & $73^{\circ}$ & 1 & 0.8 & 0 & 0 & 4 & 3.2 & 0 & 0 \\
\hline 6. & 16.9 & $75^{\circ}$ & 0 & 0 & 3 & 31.6 & 3 & 24.4 & 1 & 1.2 \\
\hline 7. & 16.4 & $77^{\circ}$ & 0 & 0 & 1 & 12.7 & 5 & 24.0 & 1 & 2.2 \\
\hline 8. & 15.9 & $75^{\circ}$ & 0 & 0 & 3 & 12.1 & 5 & 24.0 & 0 & 0 \\
\hline 9. & 15.4 & .. & 2 & 6.0 & 4 & 23.4 & 1 & 8.8 & 1 & 4.0 \\
\hline 10. & 14.9 & $75^{\circ}$ & 0 & 0 & 0 & 0 & 5 & 26.0 & 0 & 0 \\
\hline $11 \ldots$ & 14.4 & $75^{\circ}$ & 0 & 0 & 0 & 0 & 5 & 8.7 & 1 & 6.6 \\
\hline $12 \ldots$ & 13.9 & $73^{\circ}$ & 1 & 3.5 & 0 & 0 & 2 & 8.5 & 0 & 0 \\
\hline $13 \ldots$ & 13.4 & $75^{\circ}$ & 1 & 14.8 & 0 & 0 & 0 & 0 & 0 & 0 \\
\hline $14 \ldots$ & 12.8 & $75^{\circ}$ & 0 & 0 & 0 & 0 & 2 & 1.7 & 0 & 0 \\
\hline $15 .$. & $\ldots$ & $\ldots$ & .. & $\ldots$ & . & $\cdots$ & .. & $\ldots$ & .. & $\ldots$ \\
\hline $16 \ldots$ & 12.4 & $75^{\circ}$ & 2 & 1.7 & 2 & 3.5 & 0 & 0 & 1 & 0.8 \\
\hline $18 \ldots$ & 11.9 & $73^{\circ}$ & 1 & 0.9 & 0 & 0 & 4 & 12.4 & 0 & 0 \\
\hline $20 \ldots$ & 11.5 & $\ldots$ & 1 & 0.4 & 1 & 2.7 & 1 & 0.9 & 0 & 0 \\
\hline 22. & 10.9 & $75^{\circ}$ & 1 & 0.9 & 4 & 25.2 & 8 & 12.6 & 1 & 0.9 \\
\hline $24 \ldots$ & 10.5 & $75^{\circ}$ & 3 & 1.3 & 1 & 8.1 & 2 & 10.8 & 0 & 0 \\
\hline 26. & 9.9 & $75^{\circ}$ & 0 & 0 & 1 & 7.3 & 3 & 16.4 & 0 & 0 \\
\hline 28. & 9.5 & $\ldots$ & 1 & 0.9 & 2 & 9.7 & 2 & 17.4 & 0 & 0 \\
\hline \multicolumn{3}{|c|}{ Total no. and wt. } & & $81.2 \mathrm{lbs}$. & & $136.3 \mathrm{lbs}$. & & 210.9 lbs. & 8 & $19.0 \mathrm{lbs}$. \\
\hline \multicolumn{3}{|c|}{ Total volume $\nmid$. . } & \multicolumn{2}{|c|}{$1.02 \mathrm{ft}^{3}$} & \multicolumn{2}{|c|}{$1.70 \mathrm{ft}^{3}$} & \multicolumn{2}{|c|}{$2.64 \mathrm{ft}^{3}$} & \multicolumn{2}{|c|}{$0.24 \mathrm{ft}^{3}$} \\
\hline \multicolumn{3}{|c|}{ Av. number of mounds/day. } & \multicolumn{2}{|c|}{0.71} & \multicolumn{2}{|c|}{0.79} & \multicolumn{2}{|c|}{2.14} & \multicolumn{2}{|c|}{0.29} \\
\hline \multirow{2}{*}{\multicolumn{3}{|c|}{$\begin{array}{l}\text { Av. wt./mound. } \\
\text { Area of systems. }\end{array}$}} & \multirow{2}{*}{\multicolumn{2}{|c|}{$4.06 \mathrm{lbs}}}$. & \multicolumn{2}{|c|}{$6.20 \mathrm{lbs}}$. & \multicolumn{2}{|c|}{$3.52 \mathrm{lbs}}$. & \multicolumn{2}{|c|}{$2.38 \mathrm{lbs}}$. \\
\hline & & & & & \multicolumn{2}{|c|}{945 sq. ft. } & \multicolumn{2}{|c|}{792 sq. ft. } & \multicolumn{2}{|c|}{576 sq. ft. } \\
\hline
\end{tabular}

* Soil moisture calculated from core samples at 6- to 12-inch depth; soil temperature taken at 1-foot depth.

+ Volumes of burrows estimated from weight of mounds on the basis that one cubic foot of soil weighs 80 lbs (density of about 1.3),

can easily be demonstrated by walking along the top of a levee when the ground is soft and noting how frequently it caves underfoot. Presumably, these tunnels are not open along their entire length, and any connections between individual systems are probably plugged. Ingles (1952) states that adjacent burrows are never continuous and thinks that neighboring gophers "hear each other digging and do not encroach upon the home ranges of one another." He cites one instance in which systems of a juvenile female and an adult male were separated by at least a 120 centimeter corridor, which was crossed by only one fully plugged burrow.

The majority of nests are also located in or under field levees. Of 17 nests found in the nine excavated systems, only six were outside the limits of the levees, including the one in system D (noted above as the only burrow entirely outside of levees). 
POCKET GOPHER IN A FLOOD-IRRIGATED ALFALFA FIELD NEAR TIME AND SOIL CONDITIONS FOLLOWING IRRIGATION

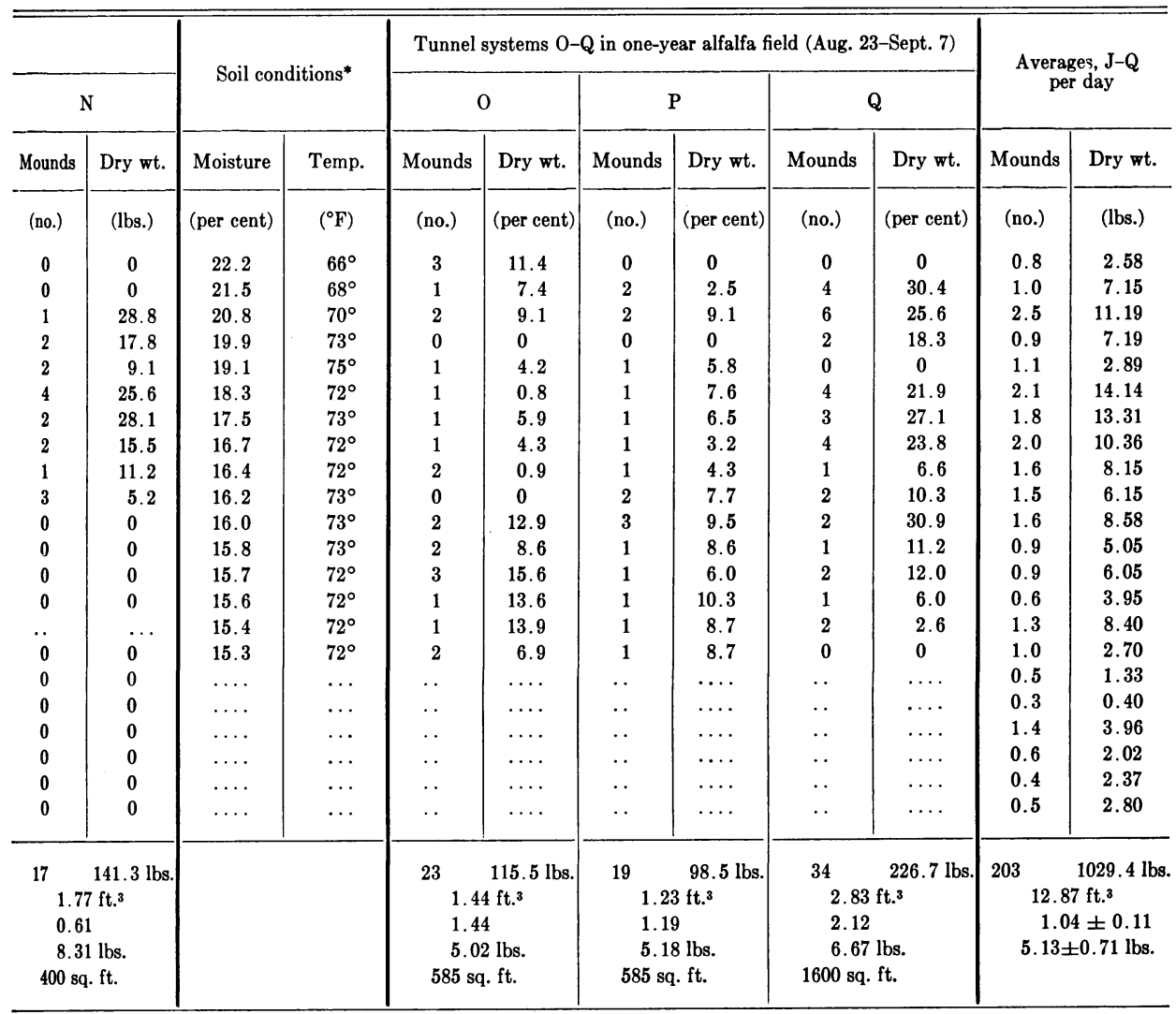

\section{Burrowing in Relation to Irrigation}

Considerable individual variation was observed in the rate of burrowing following flooding of the fields (table 2). Because of the small number of systems studied (eight) and the large fluctuations involved, it is obvious that only tentative conclusions can be drawn from these data. Furthermore, the analysis of burrowing activity is based only on number and size of surface mounds produced. This can give only a partial estimate of digging rates since the gopher may deposit excavated earth underground in old tunnels or abandoned chambers. Nevertheless, it seems reasonable to suppose that surface mound production is at least a crude index of burrowing activity, and that major trends may be established using statistically safeguarded averages of even a small number of systems. The data are summarized in table 2 and figures 5 and 6.

Time Trends. The first day after flooding the fields, there was little or no surface indication of burrowing (table 2). Only three of the eight systems 
showed any new mounds at this time. These first mounds were composed of muddy lumps, presumably made in repairing cave-ins, cracks, and other flood damage. On the second or third day as the soil became drier and more friable, the gophers began to burrow actively again, increasing the number of new surface mounds and the amount of earth brought to the surface. One system $(\mathrm{K})$ was exceptional in that no surface evidence of renewed burrowing appeared until the sixth day after irrigation. This system was probably

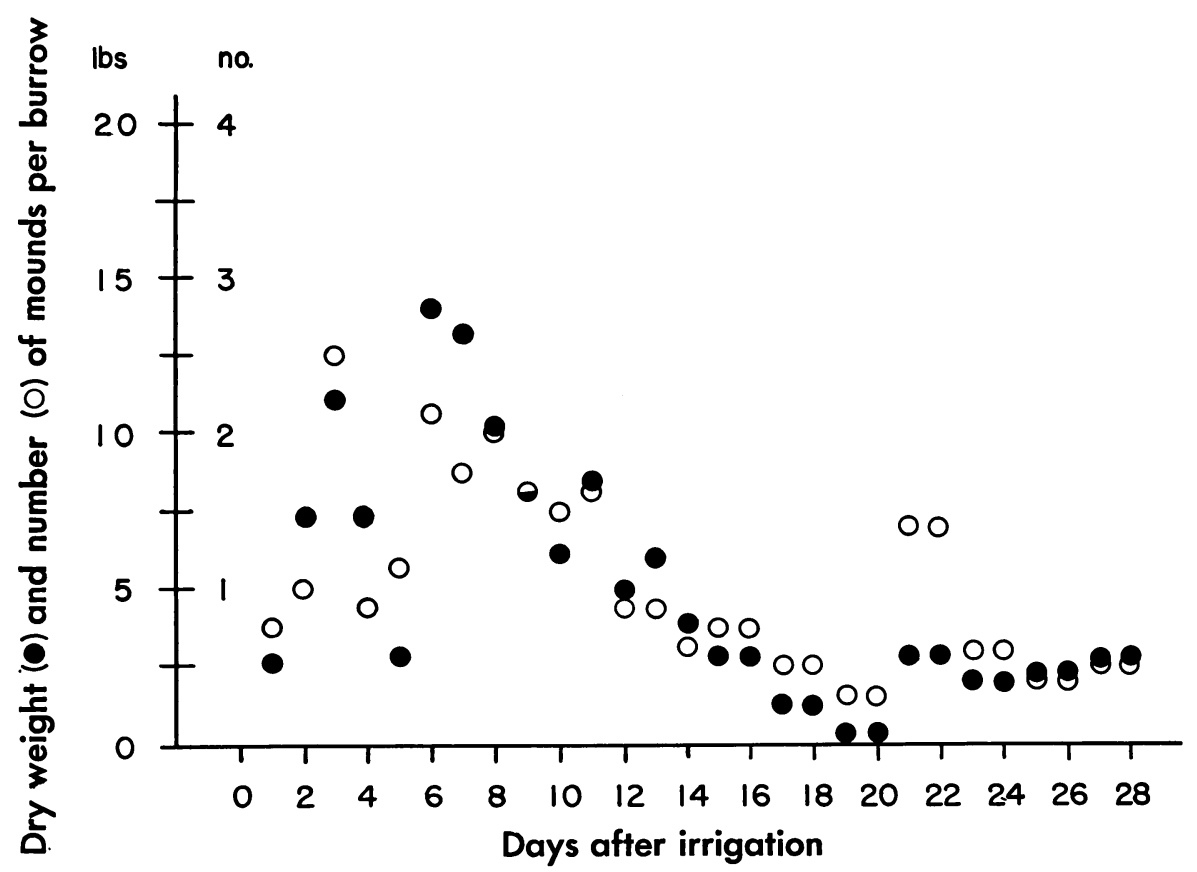

Fig. 5. Time trends in burrowing activity of gophers in an alfalfa field at Davis following flood-irrigation. Data points represent averages of eight systems, through 16 days and five systems after the sixteenth day.

abandoned during irrigation and not reoccupied or invaded by another gopher until the sixth day afterward.

The sequence of renewed burrowing activity after irrigation was somewhat irregular. In three of the systems $(J, K$, and L), a cyclical pattern was evident. An initial period of rather intense digging lasted four to ten days. This was followed by a lull of several days, during which few if any new surface mounds appeared; then a second period of extensive excavation was observed. During the initial period, relatively huge amounts of earth were pushed to the surface by the industrious burrowers. In system $\mathrm{K}$, for example, 11 mounds appeared in four days and totaled nearly 80 pounds dry weight, representing an excavation of about one cubic foot of soil by a gopher perhaps weighing $1 / 4$ to $1 / 3$ pound (the average weight of females and males of this species being 112 and 153 grams, respectively [Miller, 1952]). The six-day lull following this prodigious effort could be interpreted either as a resting 
period, or as a time when the gopher was still digging but pushing the excavated earth into abandoned tunnels or chambers instead of piling it on the surface.

In one system $(\mathrm{N})$, surface mound production continued for eight days at

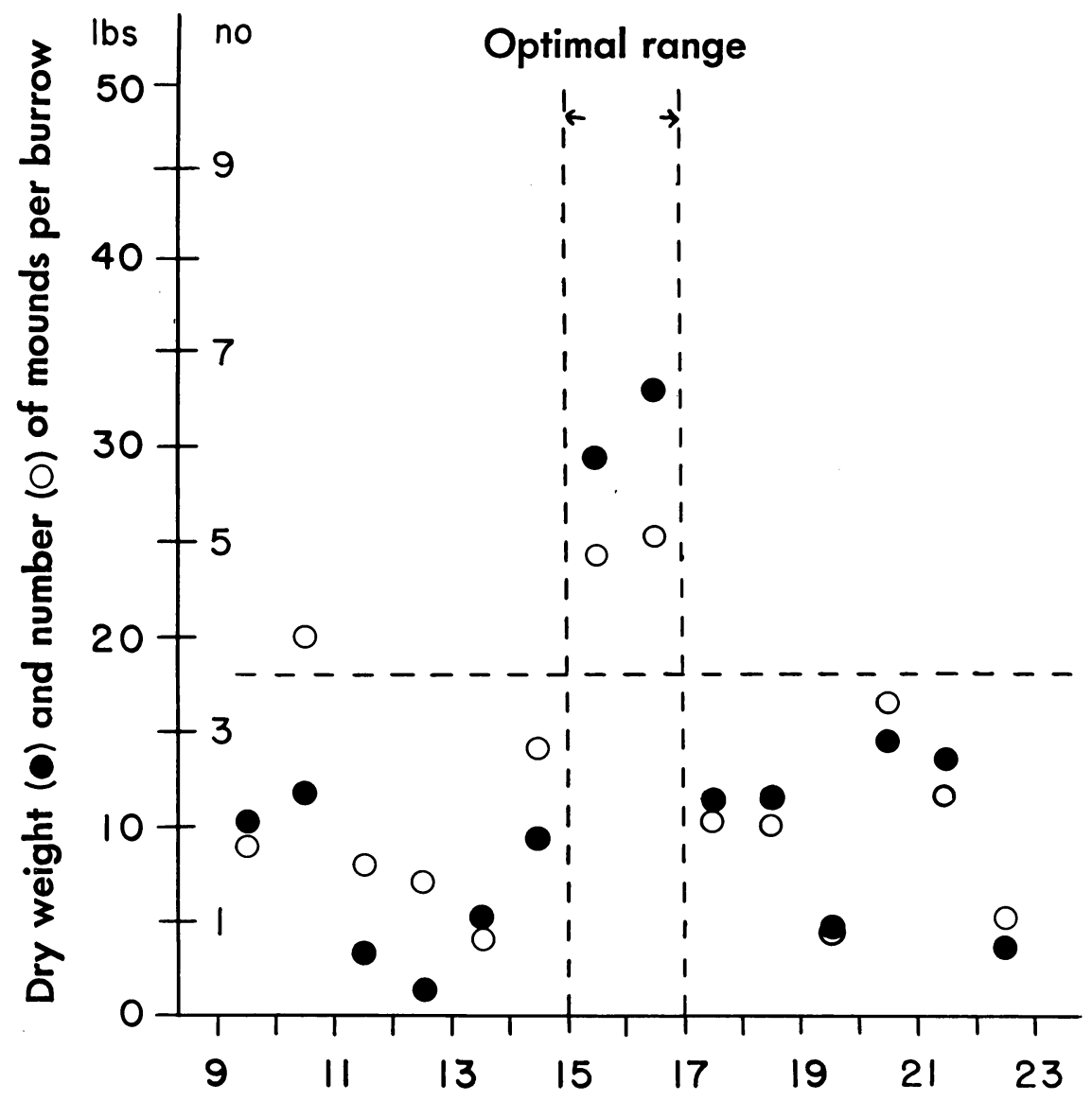

Soil moisture, 6-12 inches, per cent dry weight

Fig. 6. Relation of burrowing activity of gophers to soil moisture in a flood-irrigated alfalfa field at Davis.

a fairly high rate. It then ceased altogether with no new mounds appearing through the twenty-eighth day after irrigation, the last day of observation. The apparent cessation of burrowing activity in this system might be attributed to death or dispersal of the occupant, or, less likely, to disposal of all excavated earth underground. Another system (O) showed an abrupt increase in weights of surface mounds on the eleventh to sixteenth day after irrigation. 
General trends of gopher burrowing in flood-irrigated alfalfa fields are clearly evident in graphs of pooled excavation data for the eight systems (fig. $5)$. Beginning slowly on the first day after irrigation, mound production reached its highest levels during the first week, with peaks observed on the third and sixth days. The surprisingly steep decline between these peaks, if real, may be interpreted either as a lull in burrowing activity or a period during which most of the diggings were deposited underground. Following the maximal burrowing activity of the first week, mound production gradually declined and leveled off during the second and third weeks reaching its lowest level on the nineteenth and twentieth days. During the fourth week, mound production was maintained at a slightly higher but uniform rate except for a sporadic increase in number of mounds (but not in weight) on the twenty-first and twenty-second days. After the sixteenth day, daily averages are based on five instead of eight systems; hence, they are not as reliable as during the first two weeks of observation.

Effect of Soil Moisture and Temperature on Burrowing. The rate of digging is clearly associated with the amount of moisture in the soil (fig. 6). Most digging occurred when soil moisture at 6 - to 12 -inch depth was between 15 per cent and 17 per cent. Significantly fewer surface mounds appeared when the soil was wetter or drier. The optimal range found in irrigated alfalfa fields is considerably narrower than that found for gopher burrowing in a nonirrigated, uncultivated plot in a previous study (Miller, 1948) where maximal excavating occurred when the soil moisture was between 10 per cent and 18 per cent dry weight (6- to 18-inch depth).

Soil temperature varied little during the period of observation and had no apparent effect on burrowing. Also, no influence of air temperature on mound production was detected.

Soil Turnover by Gophers. The amount of earth brought to the surface by gophers is of interest in relation to soil turnover and erosion. In alfalfa fields, according to the present study, gophers produced an average of slightly more than one mound per day representing a daily average of 5.13 pounds of soil dry weight. This is equivalent to 20.8 inches of 2.6 inch diameter tunnels per day. At this rate, a single gopher would turn over about 1,872 pounds of soil (dry weight) per year-more than a short ton wet weightbut it is a moot question whether this rate would represent a yearly average.

The amount of soil displaced per acre would depend upon the population or number of active burrows as well as the burrowing rate. The average area occupied by a system was approximately 800 square feet (see table 2 ) giving a maximum density estimate (if crowded together) of about 54 burrows per acre. The nine excavated systems, previously discussed, occupied about a quarter acre, a density of approximately 36 burrows per acre. These values are in accord with Miss Eleanor Leland's live trapping record of 69 different marked gophers taken during seven months in an acre plot in an alfalfa field on the Davis campus farmlands (unpublished data). The foregoing estimates indicate a maximal population density of the order of 50 gophers per acre in irrigated alfalfa fields, but the average would probably lie between 20 and 30 (barring control measures).

Assuming a heavy infestation of 50 gophers per acre that burrow at a 
fairly uniform rate throughout the year, the annual soil displacement would be about 93,600 pounds or nearly $463 / 4$ tons dry weight per acre. Considering that Darwin's British earthworms cast up annually as much as 18 tons of earth per acre under favorable conditions, the estimated turnover by gophers does not seem too unreasonable. It should be emphasized, however, that the above estimate is based on a large (possibly maximal) population, and on the probably incorrect assumption of a more or less constant rate of digging. Nevertheless, the importance of the gopher as an agent in soil turnover and erosion is clearly demonstrated.

Another way of estimating soil turnover by gophers is to multiply the weight of soil that must have been dug to form an average burrow system by the number of burrows in a given area. Previously, the soil weight equivalent to the average tunnel volume was calculated to be 309.6 pounds. Multiplying this value by 50 (assuming that many burrows per acre) gives an estimate of 15,480 pounds (dry weight) of soil per acre that must have been brought to the surface. The time needed for this excavation is difficult to estimate without data on long-term burrowing rates. Nevertheless, by using the previously calculated rate of mound production (5.13 pounds per day), some idea may be gained of the time required to push up the soil excavated from an average tunnel system (309.6 pounds). At this rate it would take a gopher about 60 days to do the job, or the 50 gophers in the present example would require two months to turn over $73 / 4$ tons per acre. Although this may be a minimal time estimate, since the assumed rate is based only on a 28 -day period of rather active burrowing, there is no question but that annual turnover would be many times greater than given in the present example. For even in established systems, the industrious gophers continue to burrow throughout the year-opening new tunnels and chambers, plugging old ones, and producing new mounds as they enlarge their diggings. (Although generally disregarded, excavated earth that is deposited underground might well be included in estimates of soil turnover, especially that transferred from lower depths).

How many times a year a gopher excavates the equivalent of an average burrow is problematical. If the speculation is permitted that burrowing continues through the year at the rate estimated in our example $(15,480$ pounds per acre by 50 gophers in two months) the annual turnover becomes 92,880 pounds or nearly $461 / 2$ short tons per acre, which closely approaches the estimate of 93,600 pounds obtained by the first method. Again, these values probably represent the upper extreme as they are estimated from burrowing rates obtained during a relatively brief period of high activity and a maximal population of gophers.

The estimates of annual soil displacement by the Sacramento Valley pocket gopher in alfalfa fields are many times higher than those given by other investigators (except Seton) for various other species in more natural locations (table 3). Seton's (1929) estimates are so extraordinarily high that they may be disregarded until confirmed. Some of the tabulated estimates are based on the size of earth cores in snow tunnels which are deposited on the ground when the snow melts (Grinnell and Storer, 1924). Such values tend to be conservative because much of this material, especially that deposited on slopes and in ravines, may be washed away in the spring thaw and runoff. 
Errors are compounded when annual estimates are calculated on the assumption that summer burrowing is equal to or greater than winter activity. Loss of excavated material in the present study was practically nil since mounds were collected daily or every other day for weighing during a rainless summer month. Despite these sources of error in estimates, however, it is likely

TABLE: 3

SOIL DISPLACEMENT BY VARIOUS SPECIES OF POCKET GOPHERS

\begin{tabular}{|c|c|c|c|c|}
\hline \multirow{2}{*}{ Species } & \multirow{2}{*}{ Locality } & \multicolumn{2}{|c|}{ Soil displacement per acre } & \multirow{2}{*}{ Authority } \\
\hline & & Per period observed & $\begin{array}{r}\text { Per annum } \\
\text { (estimated) }\end{array}$ & \\
\hline Thomomys monticola...... & Yosemite & 4 tons/winter & 8 tons & $\begin{array}{l}\text { Grinnell (1923) } \\
\text { Grinnell and } \\
\text { Storer (1924) }\end{array}$ \\
\hline T. monticola..... & Sierra Nevada & $\begin{array}{l}2000 \text { bu. }(=100 \text { tons } \\
/ 2-3 \text { months } \\
1500 \text { bu. } / 2 \text { days }\end{array}$ & $\begin{array}{l}400 \text { tons } \\
(? !)\end{array}$ & Seton (1929) \\
\hline T. monticola......... & $\begin{array}{l}\text { Huntington Lake region, } \\
\text { Sierra Nevada }\end{array}$ & $\begin{array}{l}1.9 \text { tons } / \text { mo. (July- } \\
\text { Oct.) (10 gophers) }\end{array}$ & $7.5+$ tons & Ingles (1952) \\
\hline$T$. fossor (?) . . . . . . . & $\begin{array}{l}\text { White River Plateau, } \\
\text { Colorado }\end{array}$ & $1865 \mathrm{bu} . / \mathrm{month}$ & & Seton (1929) \\
\hline$T$. sp.................. & n........ & 2.8 tons/winter & 5.6 tons & Shelford (1929) \\
\hline T. talpoides moorei & Wasatch Plateau, Utah & $\begin{array}{l}3.7 \text { tons/winter } \\
1.4 \text { tons/summer (par- } \\
\text { tial) } \\
\text { (4-16 gophers) }\end{array}$ & $5-61 / 2$ tons & Ellison (1946) \\
\hline Geomys breviceps brazensis & $\begin{array}{l}\text { Texas (ungrazed range) } \\
\text { Texas (overgrazed range) }\end{array}$ & $\begin{array}{l}\cdots \cdots \cdots \\
\ldots \ldots+\cdots\end{array}$ & $\begin{array}{l}0.36 \text { tons } \\
7.08 \text { tons }\end{array}$ & $\begin{array}{l}\text { Buechner (1942) } \\
\text { Ibid. }\end{array}$ \\
\hline T. bottae navus..... & $\begin{array}{l}\text { Sacramento Valley, Calif. } \\
\quad \text { (alfalfa fields) }\end{array}$ & $\begin{array}{l}1,149 \text { lbs./23 days (sum- } \\
\text { mer) ( } 8 \text { gophers, } \\
0.15 \text { acre) }\end{array}$ & $\begin{array}{l}463 / 4 \text { tons } \\
(50 \text { go- } \\
\text { phers) }\end{array}$ & $\begin{array}{l}\text { Miller (present } \\
\text { study) }\end{array}$ \\
\hline
\end{tabular}

that there is a real and considerable difference in amounts of soil turned over by gophers in alfalfa fields as compared with those in natural situations. For one reason, populations of gophers are denser in cultivated fields with abundant food and other favorable conditions than in wild land. In Ellison's study (1946), the "base population" was estimated as somewhere between four and 16 gophers per acre. Ingles (1952) based his estimate of annual turnover (71/2 English tons per acre) on an average population of 10 gophers per acre. The average daily rate calculated from Ingles' data is 4.6 pounds, which is not much less than the 5.13 pounds per day rate used in the present study. Tryon's (1947) trap censuses of various acre plots yielded from two to 30 animals per acre depending upon the soil and vegetation involved. Thus, population density seems to be the major variable involved in estimated soil turnover by gophers. Less turnover per unit area would be expected in 
mountainous areas where the gophers are smaller and less numerous and the soil is likely to be thin and rocky.

The present study was not designed to determine diurnal rhythms or seasonal variations in burrowing activity, but such are known from other studies. Tryon (1947), for example, found two peaks of gopher activity in repairing breaks made in their systems, one at dusk and the other at dawn. $\mathrm{He}$ also observed that about 60 per cent more dirt was excavated during the night than during the day, and suspected that the bulk of the burrowing was probably done at the dawn and dusk periods. Ingles (1952) likewise found a marked increase in burrowing activity of gophers between 6:00 and 9:00 A.M. and between 4:00 and 7:00 P.M.

The consensus in regard to seasonal trends in burrowing of gophers is that peak periods occur during the fall and spring in temperate climates or high altitudes, and during the rainy season in warmer localities when soil conditions, especially moisture, are favorable for digging (e.g., Criddle, 1930; Miller, 1948; Storer, 1953; and Tryon, 1947). When the ground is frozen or dry, burrowing activity as indicated by production of surface mounds decreases. In mountain meadows near Huntington Lake, California, Ingles (1952) found that “... surface mounds were only occasionally made in May and June but were common in July and reached their maximum development in August and September."

\section{Practical Applications}

Many useful suggestions for control procedures can be derived from the foregoing analyses. Since practically all methods require treatment of gophers in their burrows, the most important suggestions relate to the finding of active tunnels. For this purpose a probe is indispensable (for plan, see Miller, 1953, page 136).

Time and labor in probing for tunnels can be saved if the operator studies the distribution of mounds. In flood-irrigated fields, the concentration of tunnels in or near field levees obviously indicates that he should hunt more along the levees than between them for gopher burrow systems. His efficiency is further increased by probing near fresh mounds because tunnels in the vicinity of old eroded diggings are likely to be filled with soil and abandoned. Fresh diggings usually indicate open tunnels nearby and an occupied system.

The crescentic shape of mounds and the direction of slant of their closing plugs give the operator good clues for finding the tunnels. He should probe on the inner side of the crescent along the radius of curvature toward which the closing plug slants. It is usually futile, however, to probe in or close to the mound itself for the tunnel is likely to be plugged at least several inches beyond the mound.

A row of plugged forage holes may represent a series of laterals ascending from a main run which may easily be found by probing along the "best fitting" line between the earth plugs.

The prober can anticipate most of his "hits" at depths between six to eight inches or less and only a small percentage below 12 inches. The "drop" of the probe on hitting an open tunnel will generally be between two and 
three inches, the average diameter of tunnels being 2.6 inches. The prober should be wary of a much longer drop which usually means an underground crack rather than a tunnel although he should not discount the possibility of having probed a steep-pitched run. Baits are better placed, however, in horizontal runs so that they do not roll or slide and thus become coated with dirt. Chances of success are greatest when the soil is friable and easy to probe since gophers dig most actively at that time.

The proper spacing of bait or trap sites in a field heavily infested with gophers is difficult to prescribe exactly because it is often impossible to determine from the distribution of mounds where one system ends and the next begins. The present study indicates that the average area of a gopher burrow is about 800 square feet, which makes the average distance between burrow centers roughly 30 feet if their perimeters approximate a square or a circle. Treating at a rate of two bait placements or trap sites per system (at least two are advised to allow for misplacements), a random spacing of 15 feet would probably be adequate. In lightly infested fields, the limits of burrow systems are usually evident and they can be treated individually. After placement of baits or traps, it is best to cover the site. Otherwise the gopher is likely to bury the bait or trap with soil while plugging the opening.

The plan of gopher burrows indicates that control by gassing is theoretically unsound. The long columns of dead air in the extensive network of tunnels delay diffusion of gas and make it difficult to force toxic fumes through the burrow even under pressure. Unless the gopher is overcome immediately, it may escape to more remote parts of the burrow and barricade itself against the diffusing gas. The more extensive the system, the less chance for a quick kill. Heavy gases, such as sulfur dioxide or methyl bromide, sink into deeper parts of the system. Meanwhile the gopher finds refuge from these toxicants in the superficial tunnels. Absorption of gases by moist or porous soil lining the tunnels may also decrease the effectiveness of gassing.

Whatever the reason, critical field tests support the assertion that gases and gas bombs are relatively ineffective compared with poison baits in gopher control (Miller, 1954). Maximal kills with gases-usually requiring massive dosages-were only of the order of 50 per cent, whereas standard poison baits, such as strychnine on cut root vegetables, averaged kills of 80 to 90 per cent or better.

Poison baits succeed where gases fail because of a basic difference in operational principle. Gas must seek out the victim wherever the animal happens to be or go in its extensive burrow system and reach it with a lethal concentration. When poison baits are used, however, the victim finds the lethal agent. Gophers are easily lured by strange objects in their burrows such as traps or baits, whether clean or poisoned.

Information given herein on depths of tunnels should be useful if it seems desirable to destroy gopher burrows as a part of the control program as suggested by Storer (1945). Plowing to a depth of one foot would break up about 80 per cent of the tunnel system. But many of the nests would not be destroyed by this procedure. Only two of the 17 nests excavated were a foot or less below the surface, and nine were at least 18 inches deep. Subsoiling to two feet would give practically complete destruction sparing only a negligible 
fraction of tunnels. Certainly, eradication of burrows would discourage and delay reinvasion of gophers and is recommended whenever possible.

\section{SUMMARY}

The pattern of burrows of the Sacramento Valley pocket gopher (Thomomys bottae navus Merriam) in flood-irrigated alfalfa fields was determined by excavating and mapping nine burrow systems. The rate of gopher burrowing in relation to soil conditions and time after irrigation was analyzed by counting and weighing the mounds produced by gophers in eight other systems during a four-week period between irrigations.

1. Statistical characteristics of the "average burrow system" of gophers in alfalfa fields are: $107 \pm 21$ feet of tunnels averaging $2.6 \pm 0.08$ inches in diameter, an average tunnel volume of $3.87 \pm 0.69$ cubic feet ; $8.6 \pm 2.8$ feet of recently plugged tunnels; about two nests, and an occasional food cache; $3.8 \pm 0.7$ blind vertical or near-vertical shafts; and three mounds and 12 earth plugs. Tunnel footage ranged between 31 and 275 feet. Evidence is given that the number of mounds and the footage of plugged tunnels are doubtless many times greater than observed.

2. All but the smallest system had from one to as many as six blind vertical shafts with the longest extending to a depth of 79 inches. Their function is uncertain, but there is evidence that they may serve as sumps for normal drainage of the burrow. They are inadequate protection, however, against flooding during irrigation.

3 . The lack of clear correlation between size of gophers trapped from systems and size of the burrow indicates that the trapped animals may not have been the original occupants. This and other evidence suggest there may be considerable turnover in occupancy of established burrows in alfalfa fields.

4. Gopher burrows comprise two unequal parts-a large superficial network of feeding tunnels connected to a smaller, deep system of connected tunnels and chambers for nesting and food storage. Nearly 80 per cent of the total tunnel footage lies within 12 inches of the surface of the ground with about half this footage at the 6- to 8-inch depth (modal depth). The deep tunnel system centers at 20 to 22 inches, while underground chambers lie about 18 inches beneath the surface.

5 . Burrows tend to be concentrated in or near field levees, which, in heavily infested fields, are often extensively tunneled.

6. After flood-irrigation, gophers of alfalfa fields resume active burrowing and reconstruction on about the second day, and mound production reaches its peak during the middle and latter half of the first week. Burrowing then declines during the subsequent few weeks before the next irrigation cycle.

7. Soil moisture is the major factor regulating gopher burrowing. In alfalfa fields, the optimal range is between 15 and 17 per cent moisture content with markedly less burrowing done under wetter or drier conditions.

8. Huge amounts of soil are brought to the surface by gophers in alfalfa fields. During a four-week summer period between irrigations, each gopher in a study plot excavated an average of $1.04 \pm 0.11$ mound per day weighing $5.13 \pm 0.71$ pounds dry weight. At this rate, a single gopher would turn over about a ton of soil annually, but it is doubtful that this digging rate con- 
tinues year long. The amount of soil turnover also depends on the number of burrows or population density of gophers, the maximum being of the order of 50 per acre.

9. Some practical suggestions for improvement of gopher-control methods are given.

\section{ACKNOWLEDGMENTS}

The author is indebted to Professor Tracy I. Storer for many helpful suggestions and criticism during these studies. Also gratefully acknowledged is the valuable assistance of George S. Troxell in excavating and mapping gopher burrow systems, and of James B. Bosley in determining gopher burrowing activity after irrigation.

\section{LITERATURE CITED}

BUECHNER, H. K.

1942. Interrelationships between the pocket gopher and land use. Jour. Mammal. 23 (3) : $346-48$.

CRIDDLe, S.

1930. The prairie pocket gopher, Thomomys talpoides rufescens. Jour. Mammal. 11 (3): 265-80.

ElLison, L.

1946. The pocket gopher in relation to soil erosion on mountain range. Ecology 27 (2): 101-14.

GRINNELL, J.

1923. The burrowing rodents of California as agents in soil formation. Jour. Mammal. $4(3): 137-49$.

GRINNELL, J., and T. I. STORER

1924. Animal life in the Yosemite. Pp. 134-43. Berkeley, University of California Press. xviii $+752 \mathrm{pp}$.

Howard, W. E., and L. G. INGLes

1951. Outline for an ecological life history of pocket gophers and other fossorial mammals. Ecology 32 (3):537-44. [Lists literature on gopher burrowing to date.]

INGLES, L. G.

1952. The ecology of the mountain pocket gopher, Thomomys monticola. Ecology 33 (1) : 87-95.

MiLLeR, M. A.

1948. Seasonal trends in burrowing of pocket gophers (Thomomys). Jour. Mammal. 29 (1) : $38-44$.

1952. Size characteristics of the Sacramento Valley Pocket Gopher, (Thomomys bottae navus Merriam). Jour. Mammal. 33 (4):442-56.

1953. Experimental studies on poisoning pocket gophers. Hilgardia 22 (4) :131-66.

1954. Poison gas tests on gophers. California Agriculture 8 (10):7, 14 .

Seton, E. T.

1929. Lives of game animals. Garden City, New York, Doubleday, Doran and Company $4(1): 395-418$.

SHELFORD, V. E.

1929. Laboratory and field ecology. P. 125. Baltimore, Md., Williams and Wilkins Company, xii $+608 \mathrm{pp}$.

STORER, T. I.

1945. Field rodent control by destruction of burrows. Jour. Wildlife Management 9 (2) :156-57.

1953. Controlling field rodents in California. California Agr. Expt. Sta. Cir. 434:3-47. TRYON, C. A.

1947. The biology of the pocket gopher (Thomomys talpoides) in Montana. Montana State College Agr. Expt. Sta. Bul. 448:2-30. 
The journal Hilgardia is published at irregular intervals, in volumes of about 600 pages. The number of issues per volume varies.

Subscriptions are not sold. The periodical is sent as published only to libraries, or to institutions in foreign countries having publications to offer in exchange.

You may obtain a single copy of any issue free, as long as the supply lasts; please request by volume and issue number from:
Agricultural Publications
Room 22, Giannini Hall
University of California
Berkeley 4, California

The limit to nonresidents of California is 10 separate issues on a single order. A list of the issues still available will be sent on request. 